\title{
Strength Properties of HVFA Concrete by using Fly Ash and Silica Fume
}

\author{
R. Venkata Krishnaiah, P. Dayakar, K. Venkatraman
}

\begin{abstract}
Concrete is the most generally utilized development material on the planet. Fly Ash use is a worldwide intuition as its expansion to bond solid supplements for strong concrete. At that point the high volume fly debris has been utilized in numerous elevated structures, modern structures, water text style structures, solid streets and moved compacted solid dams. Expansion of silica smoke and Super plasticizer to high volume fly debris solid found to expand the quality properties. Fly debris improves the nature of solid, prompting the expanded assistance life of solid structures. Cements having a lot of fly debris (generally from half) are named as high-volume fly debris (HVFA) concrete. Silica smolder, which is seen as more receptive than the fly debris and it fundamentally, improves the quality of cement. In the present examination, an endeavor is made to contemplate the impact of compressive quality of high volume fly debris concrete with differing extent of silica smoke and fly debris. Concrete is supplanted by fly debris and silica rage 50 to $80 \%$ and 0 to $15 \%$ by weight individually. The compressive quality advancement of silica smolder altered high-volume fly debris blends drenched in water up to 7 to 45 days is accounted for. As the water content is low in high volume fly debris concrete, the draining is low and regularly insignificant. Setting time is minimal longer than that of traditional cement. This is a result of low concrete substance, low pace of response and high substance of super plasticizer. The examination uncovered that by keeping up a consistent measurements of superior super plasticizer alongside fly debris and silica seethe, it is conceivable to keep up an ideal droop esteem for example functionality, along these lines fulfilling the vast majority of the cutting edge basic applications. Additionally the confined impact of silica seethe on the high volume fly debris concrete with a water bond proportion of 0.40 as been examined. The outcomes show that there is a momentous increment in the compressive quality of cement on substitution of bond by silica smoke and fly debris and furthermore acquired $10 \%$ substitution of silica seethe by bond on high volume fly debris solid invigorates higher compressive in the present examination.
\end{abstract}

Keywords-Cement, Compressive strength, Fly ash, High volume fly ash concrete, Silica fume, Super plasticizer.

\section{INTRODUCTION}

The high volume fly debris (HVFA) concrete has gotten extremely well known in India during the most recent couple of decades because of different reasons, for example, to limit utilization of Ordinary Portland Cement required delivering excellent cement for various sorts of uses, execution, cost and practicability [1-5]. HVFA concrete is one of the answers for

Revised Manuscript Received on October 22, 2019.

* Correspondence Author

R. Venkata Krishnaiah *, Department of Civil Engineering, Bharath Institute of Higher Education and Research, Selaiyur, Chennai, Tamilnadu

P. Dayakar, *, Department of Civil Engineering, Bharath Institute of Higher Education and Research, Selaiyur, Chennai, Tamilnadu

K. Venkatraman, *, Department of Civil Engineering, Bharath Institute of Higher Education and Research, Selaiyur, Chennai, Tamilnadu wipe out the natural corruptions being brought about by bond industry. Concrete having huge measure of fly debris (FA) (generally from half of the absolute cover material) is named as HVFA. It has been utilized in numerous elevated structures, mechanical structures, water front structures, solid burdens and roller compacted solid dams [6,7]. FA is one of the mechanical results delivered liberally all through the world. The physical properties of a FA add to progress of solid quality. Usefulness of cement is improved with the expansion of debris in light of the expanded in glue content, increment in the measure of fines, and the round state of the FA particles. The utilization of FA may hinder the setting of cement. FA concrete is less penetrable on the grounds that FA diminishes the measure of water expected to deliver a given droop. The principle commitment of the silica flume (SF) to the quality improvement in solidified cement at ordinary restoring temperatures happens from around 3 days onwards. At 28 days the quality of SF concrete is constantly higher than the quality of the practically identical Portland bond concrete. As the extent of SF builds, the usefulness of solid reductions in any case its momentary mechanical property, for example, 28-day compressive quality improves [8-11].

\section{MATERIALS AND METHODS}

This study comprises of both preliminary and experimental, these are presented as follows:

In the preliminary investigation, both the physical and chemical properties of micro silica or silica fume, fly ash and cement were determined for checking the suitability of these materials to use as construction materials in concrete. The present examination is an exertion towards forming a superior knowledge into the impact of compressive quality on changing extent of fly debris and silica smolder concrete with a water cementitious material proportion of 0.40 and silica smoke and fly debris substitution rates of $0,5,10,15 \%$ and $50,60,70,80 \%$ individually by weight of absolute folio with water diminishing admixtures for optimizing its impact on concrete [12-15]. The samples are casted for standard size of $150 \mathrm{~mm} \times 150 \mathrm{~mm} \times 150 \mathrm{~mm}$ for 7,28 and multi day's compressive quality. Likewise examples are tried for non-damaging tests to discover compressive quality attributes, respectively by weight of total binder with water reducing admixtures for opmizing its effect on concrete. The specimen is casted for standard size of cubes $150 \mathrm{~mm} \mathrm{x}$ $150 \mathrm{~mm} \times 150 \mathrm{~mm}$ for 7,28 and 45 day's compressive strength. Also specimens are tested for non-destructive tests to find out compressive strength characteristics [16-18]. 


\section{A. Experimental Investigations}

Cement: The binder is a OPC and suitable to codal provisions.

Silica Fume (SF): A high quality very active SF supplied by Elkem India Pvt Limited was used for the present study.

Fly Ash (FA): A siliceous FA conforming to IS: 3812 (2003) Part - I from Ennore Thermal Power Plant, Chennai was used.

Fine and Coarse Aggregate: Natural sand confirming to codal provisions of $3 \mathrm{rd}$ zone and the maximum size is limited to $12.5 \mathrm{~mm}$

H2o and Chemical Admixture: Potable water and Conplast SP-430 was used $[19,20]$.

\section{RESULT AND DISCUSSION}

Compressive strength tests are conducted on samples of 150 $\mathrm{mm} \times 150 \mathrm{~mm} \times 150 \mathrm{~mm}$ at 7,28 and 45 days of curing periods and these values have been presented in table.3. The table depicts the compressive strengths at different $\mathrm{SF}(0,5$, 10 and $15 \%$ by weight of cement) and FA at 50,60,70, and $80 \%$ replacements with $\mathrm{H} 2 \mathrm{o} / \mathrm{binder}$ ratio of 0.40 . The compressive strength increases with increase of curing period when cement replaced with $50 \%$ FA and SF of 0 to $15 \%$ than cement replaced with 60 to $80 \%$ FA and SF of 0 to $15 \%$ by its weight [21-24].

In other hand, when cement is replaced with SF of percentage 0 to $15 \%$ with FA replacement of 50 to $80 \%, 10 \%$ replacement of SF gives higher compressive strength than 0,5 and $15 \%$ SF. For FA of 50 to $80 \%$ with SF 0 to $15 \%$, rebound number trends to increases continuously i.e. at initial replacements of $\mathrm{FA}$ and $\mathrm{SF}$, rebound number decreases. In general, it is observed that at $10 \%$ SF replacement with FA 50 to $80 \%$, rebound value increases. Higher Rebound value indicates the good quality concrete and confirmed to codal provisions. Increasing trends of silica fume shown higher USPV value, where fly ash kept constant for each silica fume percentages. Ultra Sonic Pulse Velocity values were tabulated in table. 4 and the higher and lower values were observed as 4.0 and $2.9 \mathrm{~km} / \mathrm{sec}$ at $0.40 \mathrm{H} 2 \mathrm{o} /$ binder ratio. Compressive strength graphs were presented in figure 1 to 5 .

Table 1: Physical and Chemical Properties of Materials

\begin{tabular}{|c|c|c|c|}
\hline Properties & Cement & Fly Ash & $\begin{array}{l}\text { Silica } \\
\text { Fume }\end{array}$ \\
\hline $\mathrm{G}$ for binder & 3.15 & 2.09 & 2.2 \\
\hline Std Con $(\%)$ & 34 & - & - \\
\hline $\mathrm{T}_{\text {Initial }}$ (Minutes) & 240 & - & - \\
\hline $\mathrm{T}_{\text {Final }}$ (Minutes) & 300 & - & - \\
\hline Status & - & Powder form & Powder form \\
\hline Type of FA & - & TypeF & - \\
\hline $\begin{array}{c}\text { Chemical } \\
\text { Composition } \\
(\%)\end{array}$ & & & \\
\hline $\mathrm{SiO}_{2}$ & 25.02 & 60.78 & 88.7 \\
\hline $\mathrm{Al}_{2} \mathrm{O}_{3}$ & 6.26 & 24.67 & $0.4-0.5$ \\
\hline $\mathrm{Fe}_{2} \mathrm{O}_{3}$ & 1.24 & 6.76 & $0.3-0.6$ \\
\hline $\mathrm{MgO}$ & 2.28 & 0.99 & $0.6-1.2$ \\
\hline
\end{tabular}

Table 2: Physical and Mechanical

Characteristics of Aggregates Used

\begin{tabular}{|c|c|c|}
\hline Particulars & $\begin{array}{c}\text { Coarse } \\
\text { Aggregate }\end{array}$ & $\begin{array}{c}\text { Fine } \\
\text { Aggregate }\end{array}$ \\
\hline $\begin{array}{c}\text { G for Aggregate } \\
(\%)\end{array}$ & 2.7 & 2.6 \\
\hline $\begin{array}{c}\text { Water Absorption } \\
\text { Unit weight (t/m3) }\end{array}$ & 1.17 & 0.6 \\
\hline $\begin{array}{c}\text { Los Angeles Abrasion } \\
\text { value (\%) }\end{array}$ & 27 & 1.61 \\
\hline Elongation index (\%) & 18 & - \\
\hline Flakiness Index (\%) & 30 & - \\
\hline
\end{tabular}

Table 3: Compressive Strength Results

\begin{tabular}{|c|c|c|c|c|}
\hline \multirow{2}{*}{$\begin{array}{l}\text { Fly } \\
\text { ash }\end{array}$} & \multirow{2}{*}{ SF(\%) } & \multicolumn{3}{|c|}{$\begin{array}{c}\text { Comp. Strength } \\
\text { (Mpa) }\end{array}$} \\
\hline & & 7 Days & 28 Days & 45 Days \\
\hline 50 & 0 & 19.0 & 25.0 & 27.5 \\
\hline 60 & 0 & 15.5 & 22.5 & 23.5 \\
\hline 70 & 0 & 11.0 & 14.5 & 16.0 \\
\hline 80 & 0 & 7.5 & 9.0 & 12.5 \\
\hline 50 & 5 & 24 & 30.5 & 31.0 \\
\hline 60 & 5 & 18.5 & 26.0 & 26.0 \\
\hline 70 & 5 & 12.5 & 17.0 & 23.5 \\
\hline 80 & 5 & 8.5 & 10.5 & 11.5 \\
\hline 50 & 10 & 26.0 & 34.0 & 37.0 \\
\hline 60 & 10 & 19.5 & 29.0 & 30.5 \\
\hline 70 & 10 & 13.5 & 18.5 & 25.0 \\
\hline 80 & 10 & 9.5 & 13.0 & 15.0 \\
\hline 50 & 15 & 21.0 & 32.0 & 32.0 \\
\hline 60 & 15 & 16.5 & 24.5 & 27.0 \\
\hline 70 & 15 & 11.5 & 16.0 & 22.0 \\
\hline 80 & 15 & 8.0 & 11.5 & 13.0 \\
\hline
\end{tabular}

Table 4: Rebound Hammer Number and UPV values obtained at curing of 28 Days

\begin{tabular}{|c|c|}
\hline RHN (N) & UPV(km/sec) \\
\hline 34 & 3.7 \\
\hline 35 & 4.0 \\
\hline 42 & 4.4 \\
\hline 39 & 4.2 \\
\hline 36 & 3.5 \\
\hline 37 & 3.8 \\
\hline 38 & 3.9 \\
\hline 36 & 3.6 \\
\hline 38 & 3.3 \\
\hline 35 & 3.4 \\
\hline 36 & 3.5 \\
\hline 30 & 3.6 \\
\hline 23 & 2.9 \\
\hline 25 & 3.1 \\
\hline 26 & 3.4 \\
\hline 24 & 3.2 \\
\hline
\end{tabular}






Fig.1: Relationship between strength at 7 days of different Proportions of SF.

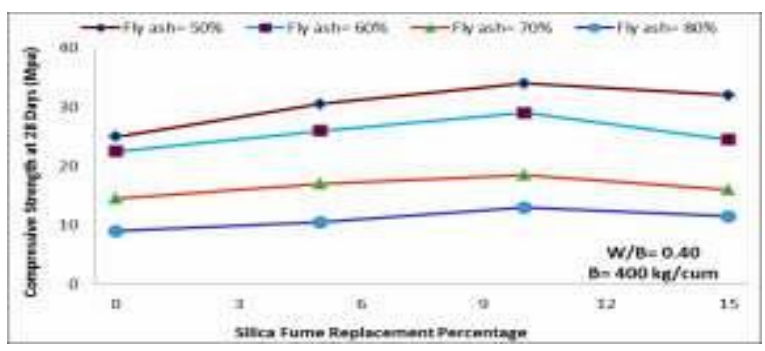

Fig.2: Relationship between strength at 28 of different Proportions of SF.

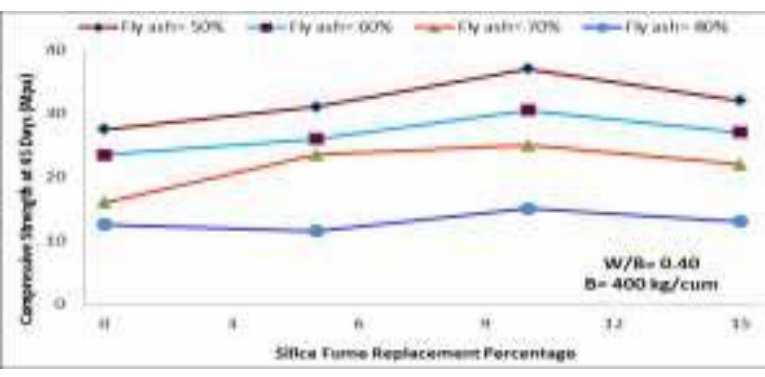

Fig.3: Relationship between strength at 45 of different Proportions of SF.

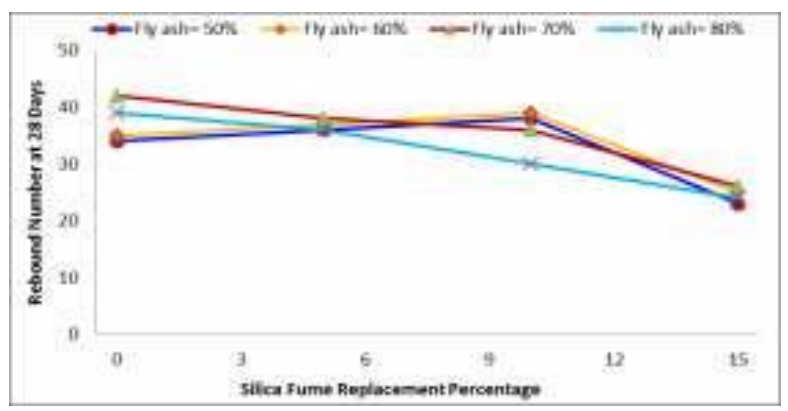

Fig.4: Relationships between RHN and of different Proportions of SF

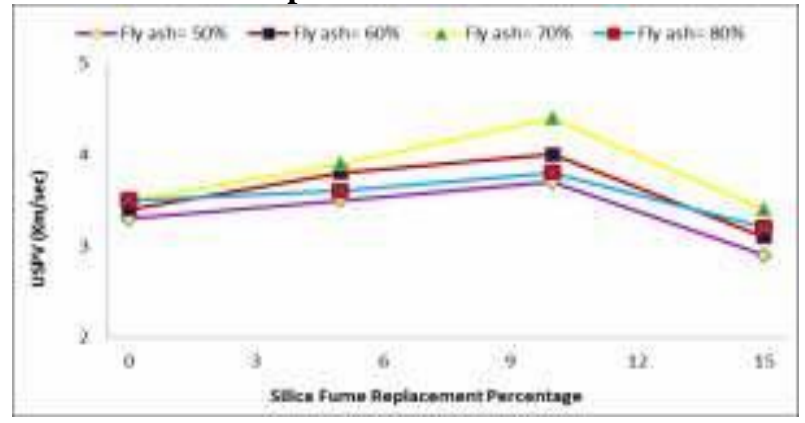

Fig.5: Relationship between UPV and of different Proportions of SF

\section{CONCLUSION}

- The strength of concrete generally decreases due to addition of FA, while presence of SF in concrete increases the strength. In the present investigation cement is replaced by high volume FA as well as SF. So that of concrete cube strength is increased up to some level of SF and FA percentages.

- $\quad$ Substitution of binder by FA and SF in various extents has come about impressive variety in the properties like cohesiveness, workability of the blend, isolation and bleeding of concrete.

- It was also observed that cement replaced by silica fume and fly ash, gives higher strength at $50 \%$ fly ash and $10 \%$ silica fume.

- With the addition of $10 \% \mathrm{SF}$ is considered as the best which gives highest compressive strength.

- $\quad$ Generally adding of FA to the concrete decreases the workability while subsequent addition of silica fume increases the workability and strength characteristics. In present studies, both were used in concrete, so that workability is increased to an acceptable limit.

- As the percentage of SF increases rebound hammer number values are increasing. However at the level of $15 \%$, the rebound hammer number values decreases marginally, which indicates that strength is reducing.

- As SF content is increased, UPV values increases up to $10 \%$ of SF addition. But at $15 \%$ of SF, the corresponding UPV values are decreasing, which indicates that strength is reducing.

- For the replacement of $10 \%$ of SF with $50 \%$ of FA, the strength at 28 days of curing was $34 \mathrm{Mpa}$, where as the strength at 7 days and 45 days were $26 \mathrm{Mpa}$ and 37 Mpa respectively.

\section{REFERENCES}

1. Andreea Voina, Brandusa Pantelimon, Georgeta Aleca, Incd Ecoind International Symposium-Simi 2011 "The Environment And The Industry" Methods for measurement, monitoring and control of NOX emissions

2. Besire Cena*, Mehush Aliu, Tahir Musliu during the year 2010 in the Journal of Environmental Application and Science published a paper on "Measurements of Emission of Gases SO2, NOx, $\mathrm{CO}$ and $\mathrm{CO} 2$ from the Burning Process in the Furnaces of Power Plant "Kosova B" vide Vol. 5 (2): 172-174 (2010)

3. Chandra H, Paliwal S, and Tripathi A, “ Mitigation Of Emission In Thermal Power Plant Using Conventional And Non-Conventiona Fuel", International Journal of Engineering Science Invention Vol 2 issue 4 Apr 2013 pp 01-06.

4. Dongmei Li, Yang Guo, Yuan Li, Pengguo Ding, Qiang Wang, Zhenqian Cao, " Air Pollutant Emissions From Coal-Fired Power Plants", Haepc electric power research institute, zhengzhou, china. Published in the Open journal of Air Pollution (2012,1,37-41)

5. Dr Malgorzata Wiatros-Motyka 'NOx control for high-ash coal-fired power plants in India . Clean Energy, Volume 3, Issue 1, 27 February 2019, Pages 24-33,

6. Eng. Florentina CĂLUGĂRU, Conf. PhD. eng. “ Installation of Low Nox Burners at $100 \mathrm{MW}$ units of Bucharest south thermal power plant" in his paper published in Termotehnica 2/2012

7. Guidelines of Continuous Emission Monitoring System issued by Central Polution Control Board during the year July 2017. 
8. James E. Staudt, Ph.D. "Control Technologies To Reduce Conventional And Hazardous Air Pollutants From Coal-Fired Power Plants", Andover technology partners, Prepared for NorthEast states for coordinated air use management (2011)

9. John H. Margeson, William J. Mitchell, Jack C. Suggs \& M. Rodney, "Integrated Sampling And Analysis Methods For Determining NOx Emissions At Electric Utility Plants", Journal of the Air Pollution Control Association, 32:12,1210-1215 published on Mar 2012 Midgett

10. Kenichi Ochi, Kenji Kiyama,Hidehisa Yoshizako, Dr. Eng.,Hirofumi Okazaki, Masayuki Taniguchi, Dr. Eng. " Latest Low-NOx Combustion Technology for Pulverized-coal-fired Boilers “, Published in Hitachi Review Vol 58 (2009), No.5.

11. Kishore B Porate, Krishna L.Thakre, Gana Shyam L. Bodhe, "Minimization Of GHG In Coal Based Thermal Power Plant", Published in the Journal of Electrical Engineering.

12. .Levaggi. D.A ,Zerrudo.R , Karels.G , Oyung.W \& Feldstein.M (2012) "An Integrated Manual Impinger Method for The Simultaneous Determination of NOx and Sox in Source Effluents, Journal of the Air Pollution Control Association, 26:8, 783-786 Published during March 2012.

13. 1Li.J and Li.W.W, "Control Technology Research on Low-NOx Combustion System in Large-Scale Coal-Fired Power Plants", Advanced Materials Research, Vols. 953-954, pp. 730-733, 2014

14. .Ministry of Environment and Forest-Guidelines for the measurement of Ambient Air Pollutant- Guidelines for Manual Sampling and Analyses- Issued by Central Pollution Control Board.

15. 15. Marc Karell and Amit Chattopadhyay (2000) -“NOx Emission Reduction Strategies in the Journal Pollution Online

16. Moo Been Chang, How Ming Lee, Feeling Wu \& Chi Ren Lai (2004) "Simultaneous Removal of Nitrogen Oxide/Nitrogen Dioxide/Sulfur Dioxide from Gas Streams by Combined Plasma Scrubbing Technology, Journal of the Air \& Waste Management Association, 54:8, 941-949,

17. .Moti L. Mittal, Chhemendra Sharma and Richa Singh "Estimates of Emissions from Coal Fired Thermal Power Plants in India "Council of Scientific and Industrial research during the year 2010

18. Nihalani S.A, Mishra Y, Juremalani J, "Emission Control Technologies For Thermal Power Plants IOP conference series : Material Science and Engineering (2018), Gujarat, India

19. Ravi K. Srivastava, Robert E. Hall, Sikander Khan, Kevin Culligan \& Bruce W. Lani 2012 in the Journal of the Air \& Waste Management Association published "Nitrogen Oxides Emission Control Options for Coal-Fired Electric Utility Boilers”, vide Vol , 55:9, 1367-1388

20. Satyashree Godka, Rohit Kumar, Navneet Singh, Himani Khandelwa, "Estimation Of GHG Emission From Indian Coal Based Thermal Power Plant", Published in IOSR journal of Engineering Apr 2012, Vol.2(4) pp: 591-597

21. .Shahzadbaig K, Yousuf M, "Coal Fired Power Plants: Emission Problem And Controlling Techniques", Published in the Journal of Earth Science and Climatic Change (2017), Ryerson university, Toronto, Canada,

22. Sujatha K, Bhavani P.G, Godavari T, Ponmagal R.S, and Su-Qun Cao. "Smart Sensor For NOx and SO2 Emissions In Power Station Boilers", Published in the Indian Journal of Science and Technology, Vol 8 (27) Oct 2015

23. Sunil P.Agarwal " in his paper on "Practical approach to SOx and NOx Measurement

24. Yuan Ji Pei, Ge Li, Xiang Qi Wang, Yun Wu Zhang, Guang Yao Feng, Yong Wang, Wei Wei, Yili Hong, Shaojun Fu, Hui Gao, Yu Xiong Li, Hong Jun Zhou, Yang Cao Tian, Lei Shang, Xiao Li Dong, Sai Dong, Liu Si Sheng, " A Low cost and high efficient facility for removal of SO2 and NOx in the flue gas from Coal Fire Power Plant "in his proceedings on the Particle Accelerator change held at Chicago during the year 2001.

\section{AUTHORS PROFILE}

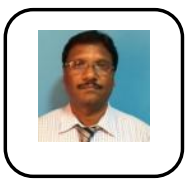

Dr. R. Venkata Krishnaiah, Professor, Department of Civil Engineering, Bharath Institute of Higher Education and Research, Selaiyur, Chennai, Tamilnadu

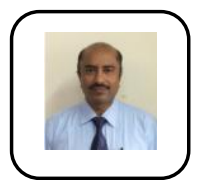

P. Dayakar, Associate Professor, Department of Civil Engineering, Bharath Institute of Higher Education and Research, Selaiyur, Chennai, Tamilnadu

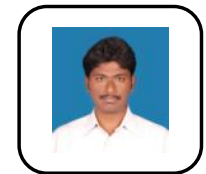

K. Venkatraman, Assistant Professor, Department of Civil Engineering, Bharath Institute of Higher Education and Research, Selaiyur, Chennai, Tamilnadu 